\title{
REGIME DE ENFITEUSE E PRODUÇÃO DO ESPAÇO EM APARECIDA DO TABOADO (MS)
}

\section{THE ENPHYTEUSIS REGIME AND THE SPACE PRODUCTION IN APARECIDA DO TABOADO (MS)}

\begin{abstract}
Letícia Alves Leonardo
Mestranda do Programa de Pós-Graduação em Geografia da Universidade Federal do Mato Grosso do Sul (UFMS/CPTL)

leh_a195@hotmail.com

Sedeval Nardoque

Professor Doutor em Geografia pela Universidade Estadual Paulista Júlio de Mesquita Filho,Câmpus de Rio Claro. Professor dos cursos de Graduação e de Pós-Graduação em Geografia da UFMS/Três Lagoas nardoque@hotmail.com
\end{abstract}

\section{Resumo}

Este trabalho resulta de estudos sobre a produção do espaço em Aparecida do Taboado, estado de Mato Grosso do Sul, objetivando compreender o processo de fundação, por meio de proprietários rurais oriundos dos estados de São Paulo e de Minas Gerais; e, analisar a contribuição da Igreja Católica, assim como, desvendar as formas de extração da renda nas terras de santo por meio do regime de enfiteuse. Para tanto, fez-se uso de embasamento teórico sobre a temática, utilizando leituras bibliográficas de vários autores, como Carlos (1992 e 2011), Corrêa (1997, 2005 e 2012), Nardoque (2002 e 2007) Sposito (1991), Sposito (1996), Oliveira (2007 e 2010), Silva (1991), Barreto (2012), Gadelha (1989), Zanotelli e Ferreira (2014). Por fim, para compreender o regime de enfiteuse e a extração de renda da terra em Aparecida do Taboado (MS), foram analisados alguns documentos disponibilizados pelo Santuário Diocesano de Nossa Senhora Aparecida, pertencente à Diocese de Três Lagoas (MS).

Palavras-chave: Produção do espaço. Renda da terra. Enfiteuse. Laudêmio.

\begin{abstract}
This work is the result of studies about the space production in Aparecida do Taboado, estate of Mato Grosso do Sul, seeking out to understand the foundation process, by means of rural landowners from the state of São Paulo and Minas Gerais; and analyze the contribution of the Catholic Church, as well as unveil the ways of income extraction in the "saint lands" through the enphyteusis regime. Therefore, theoretical basis was used on the research, using bibliographical readings of several authors, such as Carlos (1992 and 2011), Corrêa (1997, 2005 and 2012), Nardoque (2002 and 2007) Sposito (1996), Oliveira (2007 and 2010), Silva (1991), Barreto (2012), Gadelha (1989), Zanotelli and Ferreira (2014). Ultimately, to understand the enphyteusis regime and the income extraction from the land in Aparecida do Taboado (MS) were analyzed some documents
\end{abstract}


made available by the Santuário Diocesano de Nossa Senhora Aparecida, belonging to the Diocese of Três Lagoas (MS).

Keywords: Space production. Land rent. Enphyteusis regime. Laudemium.

\section{Introdução}

O presente texto é o resultado de pesquisas no decorrer das várias atividades do Núcleo de Extensão em Desenvolvimento Territorial (NEDET) do Território Rural do Bolsão, resultante de chamada pública do CNPq/MDA/2014 e desenvolvido pela equipe do Laboratório de Estudos Terra-Território $(\mathrm{LABET})^{1}$, vinculado ao Curso de Geografia da UFMS, campus Três Lagoas.

A pesquisa realizou-se com o objetivo de compreender a produção do espaço em Aparecida do Taboado(MS), bem como seu processo de fundação por meio de "pioneiros" oriundos dos estados de São Paulo e de Minas Gerais e analisar a contribuição da Igreja Católica como agente produtor, assim como, desvendar as formas de extração da renda nas "terras de santo" por meio do regime de enfiteuse naquela cidade.

Para tanto, foi necessário o embasamento teórico sobre a temática, bem como realizou-se a revisão de alguns conceitos importantes para elucidar a produção do espaço, sobretudo urbano. Os referenciais teóricos também foram importantes na compreensão do papel da Igreja Católica como agente produtor do espaço em Aparecida do Taboado (MS), pois parte dos imóveis, principalmente no centro, foi comercializado por esta instituição e gravado o regime de enfiteuse em suas respectivas matrículas no Cartório de Registro de Imóveis da Comarca, rendendo ganhos extraordinários por meio da cobrança de laudêmio, resultando em apropriação da renda da terra.

Com o intuito de verificar as doações de terras à Igreja e analisar os contratos de enfiteuse no primeiro loteamento do município, foram consultados alguns documentos, como escrituras, fotografias, disponibilizados pelo Santuário Diocesano de Nossa Senhora Aparecida.

\section{O espaço urbano}

O debate sobre espaço na Geografia vem de outros tempos e acompanha o processo de renovação do pensamento geográfico. Ao longo da construção 
epistemológica, à medida que a Geografia era renovada, surgiram novas conceituações, de acordo com os pensamentos de quem a fazia em cada época.

Para melhor entendimento de como esse espaço, sobretudo o urbano, é produzido e quem o produz, será feita uma breve discussão sobre tal e seus agentes produtores. Vale ressaltar que, para o entendimento sobre a produção do espaço urbano, é importante considerar o monopólio de uma classe sobre esse espaço: a burguesia, classe dominante, detentora da maior parte dos recursos e das terras e poder de fragmentar o espaço da maneira que lhe convém (BOTELHO, 2007. p. 16).

Dessa forma, o espaço, por meio da maximização dos valores de troca, traz benefícios para alguns grupos, em detrimento de outros, diminuindo as oportunidades de acesso à terra, sobretudo para os trabalhadores ou fazendo dele mercadoria, passível de troca, de compra e venda. Este elemento é primordial na extração da renda da terra na produção do espaço da cidade, justamente pelos empreendimentos imobiliários, tornando frações do espaço em mercadoria.

Por espaço urbano, entende-se, na visão de Corrêa (2005), como os diferentes usos da terra na cidade, ou seja, as diferentes espacialidades, reflexo da sociedade e de suas ações ao longo do tempo, fragmentado e articulado. É fragmentado, uma vez que os vários usos da terra definem áreas com funções diferentes como, por exemplo, o centro da cidade, as áreas industriais, resultando na organização espacial. É ao mesmo tempo articulado, pois cada uma de suas partes mantém relações espaciais com as demais, ou seja, esse complexo conjunto de usos da terra possui relação entre si, por meio dos fluxos de veículos e de pessoas. Essa articulação pode ocorrer ainda de forma menos visível, por meio de relações espaciais de natureza social, resultado da sociedade de classes, que envolve a prática do poder, investimentos de capital, circulação de decisões. Enfim, relações que integram, ainda que em intensidades variadas, as diferentes partes da cidade, unindo-as (CORRÊA, 2005 p. 08).

Sendo assim,

A produção do espaço resulta das ações humanas, principalmente da adição de trabalho sobre uma parcela da superfície terrestre que, além de produzir transformações em suas feições originais, têm que ser compreendidas dentro da lógica da dinâmica social sendo, por isso entendido como espaço socialmente produzido e reproduzido. (NARDOQUE, 2007, p.317).

Por ser espaço fruto das relações sociais e reflexo da sociedade, ele é desigual, refletindo a complexa estrutura social em classes (CORRÊA, 2005). Se o espaço reflete 
a estrutura social em classe, marcadamente desigual, ela vai produzir espaços desiguais. Esse espaço urbano, o espaço da cidade, é também condicionante da sociedade, no sentido de que, as obras de infraestrutura construídas desempenham papel importante na "[...] reprodução das condições de produção e relações de produção" (CARLOS, 1992, p. 23).

Há no espaço urbano diferentes formas espaciais, ou seja, diferentes usos da terra, sem existência autônoma, porque nelas se realizam diversas funções, vinculadas ao processo social, como aponta Corrêa (2005, p. 10): "Estes [os usos] são, por sua vez, o movimento da própria sociedade, da estrutura social, demandando funções urbanas que se materializam nas formas espaciais”. As formas espaciais são produzidas por agentes sociais que fazem e refazem a cidade de acordo com as necessidades da sociedade e dos conflitos de classe que emergem devido a essas necessidades.

\footnotetext{
Os atores sociais que produzem espaço têm perspectivas diferentes, alguns construindo e materializando o sonho da casa própria e outros compreendendo a produção do espaço como mecanismo de reprodução ampliada do capital através da apropriação privada da terra, das incorporações e dos empreendimentos imobiliários. Nesses termos, a cidade é pensada como um negócio. (NARDOQUE, 2007, p.317).
}

A terra e as edificações, no processo de produção do espaço urbano, representam mercadorias, uma vez que a classe dominante, como escrito, se apropriou da terra, a fim de promover o monopólio e, dessa forma, impõe domínio sobre outra classe, desprovida desse bem, levando-a a pagar para adquiri-la, ou seja, pagar para morar, o que confere à terra preços e valores. Dessa forma, o acesso à cidade, numa sociedade capitalista, se dá "[...] pela mediação do mercado, em função da existência da propriedade privada" (Carlos, 2011, p. 116).

A autora ainda afirma:

[...] o monopólio do espaço, separado das condições de produção ou moradia e a partir do desenvolvimento delas, passa a ser fonte de lucro, na medida em que entra no circuito econômico como realização (econômica) do processo de valorização que a propriedade confere ao proprietário. (CARLOS, 2011, p. 116).

Quem são esses agentes sociais e suas estratégias de atuação, são assuntos apontados na próxima seção deste artigo.

\section{Os agentes produtores do espaço urbano}

Corrêa (2005) descreve a complexa ação dos agentes produtores, pois: 
Inclui práticas que levam a um constante processo de reorganização espacial que se faz via incorporação de novas áreas ao espaço urbano, densificação do uso do solo, deterioração de certas áreas, renovação urbana, relocação diferenciada da infra-estrutura e mudança, coercitiva ou não, do conteúdo social e econômico de determinadas áreas da cidade. (CORRÊA, 2005, p.11).

Para o autor as ações dos agentes estão sujeitas a marcos jurídicos regulamentando suas atuações e, que, por vezes, esses não são neutros e refletem os interesses de alguns deles e, consequentemente, atendendo aos negócios das classes dominantes. Além do mais, os grandes capitais (financeiro, industrial e imobiliário) podem se unir em grandes corporações para controlarem a produção do espaço. Ressalta-se que a forma de atuação desses agentes varia no "tempo e no espaço", a fim de atender interesses próprios.

Sposito (1991), Corrêa (2005) e Santos (2014) elencam vários atores sociais na produção do espaço, entre eles os agentes privados - os proprietários fundiários, os promotores imobiliários, os empreendedores, os agentes financeiros, os proprietários dos meios de produção (grandes proprietários industriais e das grandes empresas), entre outros; os agentes públicos - no caso, o governo federal, estadual e municipal e a

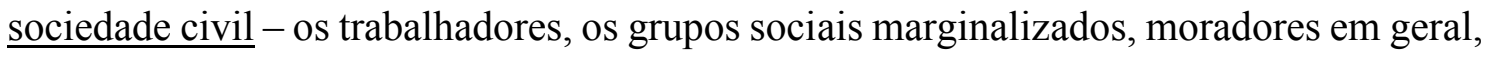
assim como os movimentos sociais e as associações de bairro.

Segundo Santos (2014), o espaço urbano advém de consequências geradas por esses agentes sociais concretos e cada formação sócio espacial nada mais é que reflexo de suas necessidades e possibilidades criadas por meio de processos e mecanismos.

Os proprietários fundiários atuam na produção do espaço urbano por meio da conversão de terra rural em terra urbana. Esses agentes imobilizam suas terras a espera que as mesmas se valorizem (entendido como aumento de preço) para fins de parcelamento (loteamento). Disponibilizam partes das terras para loteamentos e pressionam o poder público para que estas tenham o uso mais rentável possível.

Nesse sentido,

Os proprietários fundiários podem então exercer pressão junto ao Estado, especialmente na instância municipal, visando interferir no processo de definição das leis de uso do solo e do zoneamento urbano. Esta pressão não é feita uniformemente nem beneficia a todos os proprietários fundiários. Alguns, os mais poderosos, poderão até mesmo ter suas terras valorizadas através do investimento público em infra-estrutura, especialmente a viária: as cidades brasileiras fornecem vários exemplos desta prática. (CORRÊA, 2005, p. 16).

Os promotores imobiliários atuam no sentido de comprar o terreno, decidir a localização e o tamanho dos lotes e a qualidade dos prédios, a empresa que construirá as 
edificações, a propaganda e a comercialização dos imóveis ou terrenos. Dessa forma, reproduzindo e aumentando esse capital por meio do processo de produção do espaço. Sendo assim, a atuação dos promotores imobiliários é realizada de modo desigual, criando e reforçando a segregação residencial, característica da cidade capitalista. Portanto, a atuação dos grupos sociais marginalizados é inerente a muitas cidades, pois a moradia se constitui um bem de acesso seletivo, negado para parte da classe trabalhadora, justamente por não possuir dinheiro para comprar um imóvel (NARDOQUE; GIRARDI, 2009).

Esses grupos sociais marginalizados atuam na produção de "espaço vernacular", como denominado por Corrêa (2012, p.47), produzindo favelas em terras públicas ou privadas e, no caso dos loteamentos populares construídos na periferia, dão conteúdo às construções por meio de "mutirões". O autor ainda ressalta que, no processo de produção deste espaço, novos agentes sociais são criados e entram em ação, como os sujeitos ligados à criminalização e ao setor informal de produção de imóveis.

As grandes empresas industriais e financeiras também atuam como agentes de produção do espaço urbano, pois, em razão da dimensão de suas atividades, são grandes consumidoras de espaço. Essas empresas necessitam de grandes espaços para acomodação de suas atividades e, também, para expansão de seus negócios. Corrêa (2012, p. 45) aponta que "[...] a terra urbana deixou de ser estranha ao capital industrial que, a princípio, a considerava apenas como uma base necessária e insubstituível para a produção".

Para Corrêa (1997), o espaço se constitui importante campo de atuação de poderosas corporações que comandam a vida econômica e política do país. A atuação dessas grandes corporações é decisiva para a produção do espaço, na medida em que elas contribuem para:

- Produzir "company towns", bairros no interior de uma cidade, ou ainda apropriar-se, de fato ou simbolicamente, de certos espaços públicos: algumas cidades dependem de uma única empresa, que controla a maior parte dos empregos ali existentes, a exemplo de Turim (Fiat), Eindhoven (Philips) e Seatle (Boeing);

- Dar continuidade ao processo de descentralização de atividades terciárias, $[\ldots]$;

- $\quad$ Alterar a funcionalidade dos centros da rede urbana, [...];

- Criar uma nova divisão territorial do trabalho, por intermédio da difusão de inovações, envolvendo novos produtos [...] e novos meios para a produção [...];

- Através do Estado, impregnado de interesses seus, criar infraestrutura viária e energética que lhe é benéfica, ainda que possa servir a muitos outros agentes sociais e indivíduos. (CORRÊA, 2012. p. 47-48). 
A atuação do poder público, por meio das escalas federais, estaduais e municipais, tem múltiplos papéis, uma vez que, dentro da esfera do Estado, existem diferentes interesses e conflitos que se enfrentam.

Spósito (1996) menciona a existência de enorme leque de possibilidades de ação do poder público.

[...] o poder público age como empreendedor (constrói obras), como legislador (elabora leis para a gestão da cidade), como tributador (cobra impostos e taxas dos cidadãos) e como polícia (intermedia e reprime conflitos sociais), por isso, sua atuação não é neutra, porque cada atitude leva necessariamente a um resultado, ora beneficiando um, ora beneficiando outro grupo interessado. Por exemplo: aumentar impostos penaliza as pessoas mais pobres; desapropriar terrenos, penaliza proprietários; reprimir passeatas, prejudica aqueles que estão reivindicando algo, etc. (SPÓSITO, 1996, p.20).

Dessa forma, o Estado, por meio de sua atuação, visa, em linhas gerais, criar condições para que a sociedade capitalista se reproduza. A partir do momento em que o poder público prioriza as demandas da sociedade capitalista, cria também a segregação. O Estado, além de seus múltiplos papéis na produção do espaço urbano, estabelece relações com outros agentes sociais, como bancos, grandes empreiteiras, empresas industriais, proprietários de terras, entre outros. Para Corrêa (2012, p. 46), nessas relações “[...] entram em jogo mecanismos de negociação, cooptação e clientelismo, aos quais a corrupção não é estranha".

Além dos agentes sociais mencionados, existem outros que participam, a algum tempo, do processo de produção do espaço. Bancos, ordens religiosas, fábricas têxteis, companhias de seguro e de previdência privada, entre outros, também estão inseridos neste processo.

\section{A igreja como agente produtor do espaço}

Alguns autores, como Vasconcelos (2012), Corrêa (1997) e Oliveira Filho; Costa (2016), caracterizam a Igreja como importante agente produtor do espaço, sobretudo do urbano. Para Vasconcelos (2012), existem cinco importantes agentes: a Igreja (dividida em clero secular e clero regular); as ordens leigas; o Estado; os agentes econômicos, a população e os movimentos sociais. O autor descreveu a atuação da Igreja Católica na cidade de Salvador, pontuando:

No caso do clero secular, pode ser destacada a divisão da cidade através da criação de paróquias com suas igrejas matrizes. Quanto ao clero regular, tanto 
na implantação estratégica dos conventos como a propriedade de casas e terrenos foram fundamentais. (VASCONCELOS, 2012. p. 91).

Os conventos tiveram papel importante na expansão urbana e serviram, muitas vezes, de hospedaria, diante da precariedade da cidade, contudo, posteriormente, foram transformados em quartéis (VASCONCELOS, 2012).

Corrêa (1997) também classificou a Igreja como agente social, destacando mais outros quatro: o Estado, as empresas, as instituições (dioceses, paróquias católicas, sé) e os grupos sociais.

As ordens religiosas, destaque para a Igreja Católica, têm importância significativa na economia, na cultura, na política e, também, para a formação dos núcleos urbanos e no desenvolvimento das cidades no Brasil. Muitas vezes foram responsáveis pela consolidação das primeiras vilas e cidades, evidenciando, assim, o papel preponderante do poder religioso na formação de muitos municípios (OLIVEIRA FILHO; COSTA, 2016).

As missões religiosas, que adentravam o território brasileiro, ao longo da história, deram origem a pequenas vilas e povoados. Como foi o caso das missões de Parangaba, Caucaia, Paupina, das serras da Ibiapaba, de Baturité e dos Cariris Novos, e ganharam novos topônimos, respectivamente, os de Arronches (atual Parangaba), Soure (atual Caucaia), Messejana, Vila Viçosa Real, Monte-Mor o Novo da América (atual Baturité) e Vila Real do Crato no Ceará (JUCÁ NETO, 2012).

Desde o Brasil Colônia, a Igreja se configura como importante agente produtor do espaço, seja pela formação das primeiras vilas e cidades e, nos dias atuais, como proprietário fundiário, promotor imobiliário, sendo responsável também pela realização e comercialização de loteamentos. Conforme apontou Abreu (1997):

Os patrimônios religiosos não foram uma peculiaridade do período colonial [...], a expansão do café pelo oeste paulista e pelo norte do Paraná, em pleno século XX, se apoiou fortemente nesses patrimônios, que deram origem a um sem-número de núcleos urbanos [...].” (ABREU, 1997, p. 234).

Nardoque (2007), ao escrever sobre a doação de terras para os santos, apontou:

Era comum o ritual do levantamento da cruz e a solenidade da missa rezada por padre da paróquia mais próxima [...]. Muitas vezes, por vontade do fundador ou da exigência da Igreja, as doações eram feitas, sejam de terras rurais, sejam de terras ao redor do futuro templo. (NARDOQUE, 2007, p. 364). 
Grande parte das cidades paulistas, fundadas durante o século XIX e ao longo da Companhia Estrada de Ferro do Noroeste do Brasil (CEFNOB), originou-se de patrimônios religiosos. Ghirardello (2002), em seu trabalho sobre a formação de núcleos urbanos ao longo da CEFNOB, escreveu que os povoados eram originados a partir da doação de parcelas de terras à Igreja Católica, por parte de latifundiários. A Igreja Católica ficava responsável de zelar do futuro povoado formado, sob a proteção de um santo. Os interesses dos proprietários de terras com a doação eram diversos, muitos deles a faziam como forma de pagamento de promessas feitas a santos, por algum milagre concedido, outros com interesse na formação de uma cidade, valorização das terras ou até mesmo para atrair mão de obra para as fazendas. O autor ainda aponta os interesses também relacionados à intenção de unir, novamente, os poderes entre a Igreja e o Estado, sendo que até a República, a Igreja exercia algumas funções como, registros de nascimento, certidões de óbito, casamentos e até mesmo registros de imóveis, que, após 1889, passaram a ser desempenhadas pelo Estado.

Oliveira Filho e Costa (2016), ao analisarem as formas de atuação e domínio do espaço por parte da Igreja na cidade de Crato (CE), ressaltam que é notória a forma como a economia formal se desenvolve em torno desses espaços de propriedade da Igreja, citando o exemplo de lojas de roupas, de calçados, produtos de beleza, departamentos alimentícios, empresas ligadas ao setor público, entre outras, relatando que, na cidade, a Igreja se apresenta por meio de uma "[...] gama de serviços ofertados, tanto do ponto de vista educacional, como ligada as áreas de lazer, hotelaria e comércio, além de atuar diretamente com enfoque na moradia" (OLIVEIRA FILHO; COSTA, 2016. p.109-111).

Rosendahl (1997) escreveu sobre a construção do espaço sagrado e a importância que o mesmo exerce na mediação entre o homem e a divindade. O espaço sagrado é aquele destinado aos crentes para a realização de suas atividades e práticas devocionais, onde ocorrem as missas, os cultos. Em contraponto, há também a formação de um espaço profano, diretamente ligado ao espaço sagrado, lugar da prática de atividades não religiosas, a área onde se concentram os comerciantes e os barraqueiros. $\mathrm{O}$ autor ainda traz a questão das cidades-cerimoniais e sua organização interna, destacando:

Estas cidades sugerem uma ordem espacial hierarquizada, centrada no espaço sagrado. Dirigidas pelo clero organizado e dirigentes diversos, essas cidades sagradas ou hierópolis eram assinaladas por templos piramidais, pátios cerimoniais, praças de mercado e terraços. As elites sacerdotais organizavam as cidades em torno do santuário que ligava o povo ao mundo sobrenatural. (ROSENDAHL, 1997, p. 127). 
O autor descreve também as cidades-santuários e a construção de arquitetura urbana para atender aos peregrinos que as visitam diariamente, citando o exemplo da cidade de Lourdes, na França. Para Rosendahl (1997), na cidade há organização para acolher os devotos, primeiro com o acesso ao lugar sagrado (templo), modernizado pouco a pouco, e depois, estabelecendo lugares para esses peregrinos se alojarem, com a construção de lugares de abrigo, desde albergues e dormitórios modestos a luxuosos hotéis ou alojamentos especializados para peregrinos doentes. Além dos espaços para receber os peregrinos, há também, na cidade de Lourdes, prédios administrativos pertencentes à igreja e áreas de comércio onde são vendidos artigos religiosos.

A Igreja Católica ainda exerce grande influência na produção do espaço, pois possui terras sob seu domínio e, com isso, além de todas as suas outras estratégias de produção, apropria-se de renda da terra por meio de contratos de enfiteuse e a cobrança do laudêmio, podendo muitas vezes, se unir a outros agentes produtores do espaço, como é o caso em Aparecida do Taboado (MS).

\section{Renda da terra}

A terra é um recurso natural limitado em termos de quantidade, mas ilimitada quanto a sua potencialidade de produção, pois será sempre cultivável, desde que tratada ou passível de edificações. Portanto, no modo de produção capitalista se tornou mercadoria, sendo apropriada como tal pela classe hegemônica no intuito de estabelecer domínio sobre outra classe, desprovida desse bem, promovendo o monopólio sobre ela, se configurando como meio de produção universal.

Segundo Oliveira (2007, p. 63), a terra "[...] não se constitui em um produto do trabalho humano, não tem valor como as demais mercadorias (que são produtos do trabalho humano) $[\ldots . .$. " e, por isso, torna-se um tipo especial de mercadoria. Esse monopólio sobre a terra, com o advento da propriedade capitalista, impõe domínio sobre as classes menos favorecidas, obrigando-as a pagar para poder usufruir dessa mercadoria especial, seja para produção ou para moradia. Dessa forma, passou a ter preço, a valer dinheiro, a ter valor de troca, tornando-se mercadoria do sistema e gerando renda da terra.

Para Zanotelli e Ferreira (2014, p. 39), a terra possui dupla face. Por um lado, ela tem valor de uso, quando se configura como meio de existência, por outro lado, é expressa como valor de troca, sendo que, quem não possuiu terra, necessita dela como valor de uso. 
O conceito de renda da terra é importante para a compreensão da questão agrária e, também, urbana, uma vez que, em ambas, a terra se caracteriza como elemento fundamental. A renda da terra é lucro extraordinário e permanente, podendo ocorrer tanto no campo como na cidade. Nardoque (2002), ao falar sobre renda da terra, descreveu-a como:

[...] um lucro extraordinário, suplementar, permanente, que ocorre tanto no campo como na cidade. Ela é também denominada de renda territorial ou renda fundiária. Sendo, pois, a renda da terra um lucro extraordinário permanente, ela é produto do trabalho excedente, ou seja, é fração da mais-valia. É, mais precisamente, componente particular e específico da mais-valia. (NARDOQUE, 2002, p.58-59).

Para Oliveira (2007), a renda da terra existe antes mesmo do desenvolvimento do modo de produção capitalista. A renda da terra, em sua forma pré-capitalista, ou seja, menos desenvolvida, era diretamente produto excedente, ou seja, era parte da produção destinada ao proprietário fundiário, como forma de pagamento pela autorização para cultivar a terra. Sendo que, a parte da produção necessária para a alimentação dos camponeses foi retirada, ou seja, era tudo o que sobrava da produção, depois de retirar o necessário para o autoconsumo. Dessa forma, a renda da terra se caracterizava como pagamento, por parte dos sujeitos não possuidores de terras, mas necessitados da mesma para trabalhar ou para morar, aos proprietários de terras pelo direito de uso desta terra.

No modo de produção capitalista, a renda da terra, em sua forma mais desenvolvida:

[...] é sempre sobra acima do lucro (do lucro médio que todo capitalista retira de sua atividade econômica, aliás, sem esse lucro médio nenhum capitalista colocaria seu capital para produzir). Ela é, dessa forma, sobra acima da fração do valor das mercadorias, que nada mais é do que mais-valia, ou seja, trabalho excedente. (OLIVEIRA, 2007, p. 43).

Para Oliveira (2010), quando o capitalista compra a terra, compra o direito de extrair a mais-valia social, uma vez que é tributo pago por toda a sociedade. Quando alguém compra a terra e se, algum tempo depois for querer vendê-la, o preço não será o mesmo do momento da compra, sendo superior. Isso ocorre porque a terra se valoriza (entendido como aumento de preço), capitalizando a renda (SILVA, 1991. p. 74).

Silva (1991, p.74) ainda aponta que “[...] a terra não se valoriza em si, a sua valorização é feita nos diversos ramos da produção, onde há geração de mais-valia e parte dela flui para o mercado de terra". Para Nardoque (2002 e 2014), a renda fundiária é fração da mais-valia, pois o trabalhador tem que produzir mais-valia, realizada não só em forma de lucro, mas também na forma de renda, sendo apropriada pelo proprietário da terra. 
A renda fundiária capitalizada tem, como descreve Silva (1991), semelhança com a poupança. Na poupança o dono do dinheiro aplica o mesmo em um banco para render juros, sendo que o aplicador nada faz, só aguarda o rendimento de juros, para quando for retirar o dinheiro, ganhará mais dinheiro. O mesmo acontece com a terra, o proprietário compra a terra e espera o melhor momento para vendê-la. Só a preserva, o que, posteriormente, lhe garantirá maior renda, mais dinheiro.

\section{Modalidades de renda da terra}

A renda da terra pode aparecer sob diferentes formas: absoluta, diferencial I e II e de monopólio. A absoluta se caracteriza quando existe o monopólio sobre a terra e para que a mesma seja posta para produzir, por aqueles que não a possuem, seu proprietário realiza a cobrança de tributos. É obtida pelas características físicas do solo, como relevo, área, entre outras e só ocorre quando há elevação maior nos preços dos produtos do que nos preços da produção, aumentando a demanda por mais produtos e por mais terra, dessa forma, extraindo fração da mais-valia dos trabalhadores (NARDOQUE (2002) e NARDOQUE; GIRARDI (2005)).

Para Oliveira (2007, p. 43-44), a renda absoluta da terra é resultante da “"[...] posse privada do solo e da oposição existente entre o interesse do proprietário fundiário e o interesse da coletividade". Resulta do fato de a propriedade da terra ser monopólio de uma classe que cobra tributo da sociedade inteira para colocá-la para produzir.

O autor ainda aponta que o lucro extraordinário obtido da renda absoluta é diferente do lucro obtido na diferencial I e II, pois,

[...] não é fração do trabalho excedente dos trabalhadores daquela terra em particular, mas sim, fração da massa de mais-valia global dos trabalhadores em geral da sociedade. Ou seja, toda a sociedade é obrigada a pagá-lo (este lucro extraordinário chamado renda da terra absoluta) aos proprietários de terras. (OLIVEIRA, 2007, p. 55).

Segundo Silva (1991, p. 77), “[...] a renda absoluta é explicada pelo monopólio privado da terra, enquanto quantidade limitada. Significa dizer que toda terra, por pior que seja, paga uma renda [...]", pois para que o capitalista pague essa renda, o valor de mercado do produto a ser produzido tem que ser o suficiente para cobrir o custo da produção e o real valor do produto. 
A renda diferencial ocorre mediante concorrência entre produtores e é explicada, segundo Oliveira (2007), “[...] pelo monopólio da terra enquanto qualidade diferenciada [...]" e ao conceituá-la aponta que "[...] a renda da terra diferencial resulta do caráter capitalista da produção e não da propriedade privada do solo, ou seja, ela continuaria a existir se o solo fosse nacionalizado" (OLIVEIRA, 2007, p.44). E destacou ainda:

[...] a renda diferencial é, portanto, a diferença entre o preço individual de produção de cada produtor em particular (que tem a sua disposição solos mais férteis, por exemplo) e o preço de produção geral que é formado a partir dos preços de produção dos piores solos cultivados. (OLIVEIRA, 2007, p.44).

A renda diferencial é classificada em I e II. A I é determinada pelas diferentes características do solo, como fertilidade, uma vez que solos mais férteis (ou outros atributos naturais), resulta em maiores rendimentos aos produtores, pois permitem menores gastos para produzir e, a localização, ou seja, a proximidade das terras em relação aos mercados consumidores, pois quanto mais distantes, maior o gasto com transporte dos produtos. A renda diferencial I só existe a partir do momento em que a terra é colocada para produzir (BARRETO, 2012), (NARDOQUE, 2007), (OLIVEIRA, 2007).

A renda diferencial II ocorre devido à intensificação de investimentos feitos pelos proprietários nas terras a fim de melhorar as qualidades naturais do solo, com equipamentos de drenagem, de irrigação, adubação, etc. (BARRETO, 2012), (NARDOQUE, 2007), (OLIVEIRA, 2007).

A renda de monopólio, segundo Nardoque (2007, p. 323) “[...] resulta do preço de monopólio de uma certa mercadoria produzida, que é determinado pelo desejo e pela capacidade de pagamento dos compradores, não dependendo do valor dos produtos ou mesmo do preço geral de produção".

Para Oliveira (2007, p. 44), a renda de monopólio “[...] é também lucro suplementar oriundo, derivado, de um preço de monopólio de certa mercadoria produzida em uma porção do globo terrestre dotado de qualidades especiais".

Sendo assim, esse tipo de renda ocorre quando há certa disputa por terras propícias à produção de culturas que estejam em alta no mercado. Essa terra terá preço bem acima da média, que poderá ser paga pelo capitalista que deseja produzir, uma vez que sua produção também terá preço elevado e, dessa forma, dará para cobrir os custos da produção e ainda pagar o preço cobrado pelo proprietário fundiário ou daquele produto 
produzido naquela terra em especial, pelo consumidor da mercadoria final. Oliveira (2007) apresenta, como exemplo de renda de monopólio, a produção do Vinho do Porto.

Essas formas de renda da terra são extraídas tanto no campo como na cidade. Ao atualizar esses tipos de renda da terra (agrícola) para a terra urbana, tem-se,também,a renda absoluta e a renda diferencial I e II. Barreto (2012) aborda os tipo de renda da terra agrícola e sua transposição para a terra urbana, apoiada nos escritos de Topalov. Para a autora, a renda absoluta da terra urbana se refere à:

[...] própria existência da propriedade privada do solo autônoma e oposta ao capital. A RA [renda absoluta] representa o monopólio da terra. Seu conteúdo econômico reflete o limite entre a área urbana e a área rural. A RA existe para toda atividade capitalista de produção de espaço construído na cidade, desde que exista a propriedade privada da terra obstando a livre reprodução do capital. (BARRETO, 2012, p. 64).

A renda diferencial I é determinada pelas desigualdades de custos de produção localizados, ou seja, determinada pela potencialidade de um terreno para se construir algo, como edifícios, casas, ou algum outro empreendimento. Assim, a qualidade das terras, como menor declividade ou localização, favorecem a construbilidade ou a produção e a circulação de mercadorias ou serviços, contribuindo para que esses atributos confiramlhes renda mais elevada.

A renda diferencial II se caracteriza pelos investimentos de capital, como infraestrutura. Segundo Silva (2015, p. 230), a renda difrencial II para a terra urbana seria o "[...] sobrelucro que se pode realizar com o incremento de capital por cima do capital médio". Esse sobrelucro pode se materializar, por exemplo, no processo de verticalização das cidades. O autor ainda ressalta que esse sobrelucro só existira nas edificações construídas para atender um mercado privilegiado.

\section{O regime de enfiteuse como forma de extração de renda da terra}

Surgidos na Grécia antiga, mas copiados no Direito Romano durante o Império e, posteriormente, transposto para os feudos na Idade Média, o regime de enfiteuse e a cobrança do laudêmio caracterizam-se como formas de se extrair renda da terra. No Brasil surgiu por meio das leis/ordenações portuguesas com a chegada dos portugueses. Em Aparecida do Taboado (MS) sua instituição ocorre desde sua fundação.

Assim, 
Na Idade Média, o regime de enfiteuse foi transposto para a natureza patrimonial do Estado, organizado sob o regime feudal, pelo qual as terras tinham senhor, e quem não tinha terra sujeitava-se à condição de vassalo. Portanto, no feudalismo, o senhor feudal (senhorio) era quem tinha o direito sobre as terras mantendo o domínio direto ou pleno e, dessa forma, concedia a permissão de uso sobre suas terras, através da cessão do domínio útil aos vassalos, considerados como enfiteutas ou foreiros. (NARDOQUE, 2007, p. 359).

No Brasil o regime de enfiteuse e a cobrança de laudêmio foram introduzidos com a chegada dos portugueses, pois, devido à necessidade de ocupar o território, a Coroa Portuguesa cedeu porções de terras, primeiramente com as capitanias hereditárias e, posteriormente, com as sesmarias a particulares por meio de contratos de enfiteuse.

O domínio útil ficava com os sesmeiros, pessoas nobres ou de confiança do Rei, contudo, o domínio direto ou pleno ficava com a Coroa Portuguesa. O laudêmio, do latim laudare (aprovar, a aprovação do senhorio), ou laudemium, se caracteriza como o direito do recebimento da taxa de $2,5 \%$ sobre o preço da alienação feito quando o senhorio direto renuncia do seu direito de recompra do objeto e só pode ser cobrada sob o valor venal do terreno, tal como ele era no momento da realização do contrato, não podendo o senhorio cobrar por benfeitorias realizadas no terreno ou imóvel (NARDOQUE, 2007).

Para Nardoque (2007), os aforamentos no Brasil foram instituídos em favor de senhorios, como a Igreja, suas ordens religiosas e suas instituições como as fábricas, mas também à família imperial e a particulares.

Segundo Gadelha (1989), até 1822 o acesso à terra se dava por meio de doações como as capitanias hereditárias e as sesmarias. Contudo, com a promulgação da Lei de Terras de 1850, unificou-se a posse (uso da terra ou imóvel) e o domínio (titularidade da terra) em uma só pessoa, no caso, o proprietário. De acordo com a lei, só poderia haver ocupações de terras por meio da compra, ou seja, foi instituída a propriedade capitalista da terra, não sendo mais permitidas concessões de sesmarias e a ocupação por posse.

Contudo, a Lei de terras de 1850 não suprimiu o regime de enfiteuse, pois nessa lei, as terras urbanas não foram tratadas da mesma forma, como afirma Nardoque (2007, p. 360).

Todavia, pela Lei de 1850 , as terras nas cidades continuaram com tratamento diferenciado, permanecendo como patrimônio municipal ou religioso, de acordo com o Artigo 77. Os artigos 78 e 79 regulamentaram a cobrança do foro anual e do laudêmio, revertidos para a municipalidade ou para a Igreja, para melhoramentos e obras nas cidades. (NARDOQUE, 2007, p.360). 
Nesse tipo de contrato, o senhorio (quem possuía o domínio da terra) transferia a posse do terreno ou imóvel ao enfiteuta ou foreiro, contudo, o domínio ainda permanecia com o primeiro.

Mesmo na República, a legislação brasileira baseou-se no Direito Romano para instituir o regime de enfiteuse no Código Civil de $1916^{2}$, não vedando a instalação de novos contratos de enfiteuse. Foi somente com o Código Civil atual, aprovado em 2002, que a instituição de novos contratos de enfiteuse foi vedada, mas respeitando os instituídos, ou seja, os contratos de enfiteuse existentes antes da vigência do novo código até sua extinção são válidos e serão regidos pelo código de 1916 e leis posteriores (NARDOQUE, 2007).

O Código Civil de 1916 ainda definiu algumas características desse regime de extração de renda da terra. De acordo com o Código Civil, o contrato de enfiteuse era perpétuo, sendo transferido aos herdeiros; só poderia ser objeto de enfiteuse terras que não são cultiváveis e destinadas à construção de casas e edifícios; o imóvel aforado não poderia ser revendido sem aviso prévio ao senhorio direto, pois esse teria o direito de recompra-lo pelo prazo de trinta dias para declarar se o compraria, unificando o domínio e a posse, ou não. $\mathrm{O}$ enfiteuta também tinha direito de compra, caso o senhorio quisesse se desfazer do domínio direto.

Para ocorrer cobrança de laudêmio há que ter onerosidade e havendo deve ser dada a preferência ao proprietário, ou seja, na comercialização de imóvel gravado por enfiteuse, paga-se $2,5 \%$ de seu preço àquele que tem o domínio para abrir de seu direito de recompra.

Outra característica do regime enfiteutico:

\begin{abstract}
Outra modalidade de taxação imposta pelo regime enfitêutico é o foro anual ou pensão, taxa devida pelo foreiro ou enfiteuta ao senhorio direto, certa e invariável. Portanto, o foro tinha que ser determinado no ato do contrato de enfiteuse, não podendo mais ser reajustado. Na maioria dos casos, o foro não é cobrado, pois, com o passar do tempo, os valores tornam-se irrisórios [...]. (NARDOQUE, 2007, p. 366).
\end{abstract}

O Código Civil de 1916 ainda é claro ao pontuar que todos os aforamentos, inclusive os constituídos antes da aprovação do Código, salvo acordo entre as partes, são resgatáveis. O resgate pode ocorrer após 10 (dez) anos de constituídos, mediante pagamento de um laudêmio, no valor de 2,5\% (dois e meio por cento) sobre o valor venal do terreno e de 10 (dez) foros anuais pelo foreiro, que não poderá no seu contrato renunciar ao direito de resgate. 
Nos terrenos da Marinha também há instituições de contratos de enfiteuse, pois esses e seus acréscimos pertencem à União, conforme art.20, VII, da Constituição Federal de $1988^{3}$. Tais poderão ser concedidos a particulares por meio de enfiteuse, tendo como legislação aplicável a lei $9.760 / 46^{4}$. Dessa forma, a enfiteuse de terras públicas é permitida.

Ressalta-se que os contratos de enfiteuse ou de aforamento constituem direito real e, por isso, sua validação ocorre mediante o registro público no cartório de registro de imóveis da circunscrição dos objetos dos contratos. O regime de enfiteuse difere do arrendamento e do aluguel, uma vez que o primeiro tem caráter perpétuo, enquanto os demais são de caráter temporário, por tempo certo.

Para Nardoque (2007, p. 362), “[...] o instituto do contrato de enfiteuse permite a cobrança de taxas (laudêmio e foro) que se constituem modalidades de extração de renda da terra". Portanto, o regime de enfiteuse se caracteriza como uma forma de se extrair renda da terra na modalidade de renda absoluta. A renda absoluta se caracteriza quando existe o monopólio sobre a terra e para que a mesma seja posta para produzir, por aqueles que não possuem terra, o senhor de terras realiza a cobrança de tributos.

A Igreja Católica é a representante das "terras de santo" e apropriou-nas promovendo o monopólio sobre as mesmas, cobrando taxas de sujeitos desprovidos desse bem (a terra), pelo simples direito de cessão à ocupação. Há várias cidades no interior de São Paulo com áreas no entorno das igrejas com instituições de enfiteuses, como são os casos de Sebastianópolis do Sul, Monte Aprazível, Nipoã, Bebedouro e São José do Rio Preto (NARDOQUE, 2007).

\section{A produção do espaço urbano e o regime de enfiteuse em Aparecida do Taboado (MS)}

O município de Aparecida do Taboado localiza-se na região Leste de Mato Grosso do Sul, sua sede situa-se na latitude $20^{\circ} 05^{\prime} 12^{\prime \prime}$ Sul e longitude de $51^{\circ} 05^{\prime} 37^{\prime \prime}$ Oeste (Figura 1), com área municipal de $2.750,130 \mathrm{~km}^{2}$ e população estimada, em 2014 , de 24.078 habitantes. O município integra a Microrregião Geográfica de Paranaíba ${ }^{5}$ e o Território Rural do Bolsão. Na sede do município, desde a sua fundação, instalou-se o regime de enfiteuse na parte central da cidade, configurando-se uma característica peculiar entre os 
municípios que integram a porção leste de Mato Grosso do Sul, possibilitando a extração da renda da terra por meio da cobrança do laudêmio.

O Território Rural do Bolsão, instituído pelo Ministério do Desenvolvimento Agrário, em 2013, é composto por oito municípios, sendo eles: Três Lagoas, Água Clara, Selvíria, Paranaíba, Aparecida do Taboado, Inocência, Cassilândia e Chapadão do Sul. Possui extensão territorial de 45.929,9 $\mathrm{Km}^{2}$ e sua população estimada em 233.297 mil habitantes. Três Lagoas é o município mais populoso, com mais de 100 mil habitantes. (NARDOQUE; ALMEIDA, 2015). Na figura 2 demonstra-se a delimitação do Território Rural do Bolsão.

O Território Rural do Bolsão tem como:

[...] característica marcante [...] a concentração da população residente nas sedes municipais, totalizando $87,62 \%$ (IBGE, 2010). Em 1980 a população urbana representava $67,59 \%$ do total, o que evidencia, portanto, forte migração campo-cidade nos últimos 30 anos. A industrialização é um fenômeno recente neste Território, de forma específica em Três Lagoas, logo os municípios ainda mantêm suas economias assentadas na agropecuária, ou seja, no setor primário, com predomínio das relações centradas na dependência urbana. (NARDOQUE e ALMEIDA, 2015, p.3).

Apesar de ter população reduzida, o município de Aparecida do Taboado possui forte concentração urbana, com densidade demográfica de $8,12 \mathrm{Hab} . / \mathrm{km}^{2}$, esse fato decorre da redução da população do campo, sobretudo devido à concentração fundiária, do predomínio da pecuária extensiva (gera poucos empregos no campo) e pela presença de agricultura fortemente mecanizada, ligada ao setor sucroalcooleiro (NARDOQUE; ALMEIDA, 2015). 
Figura 1: Aparecida do Taboado (MS): localização do município e sua sede

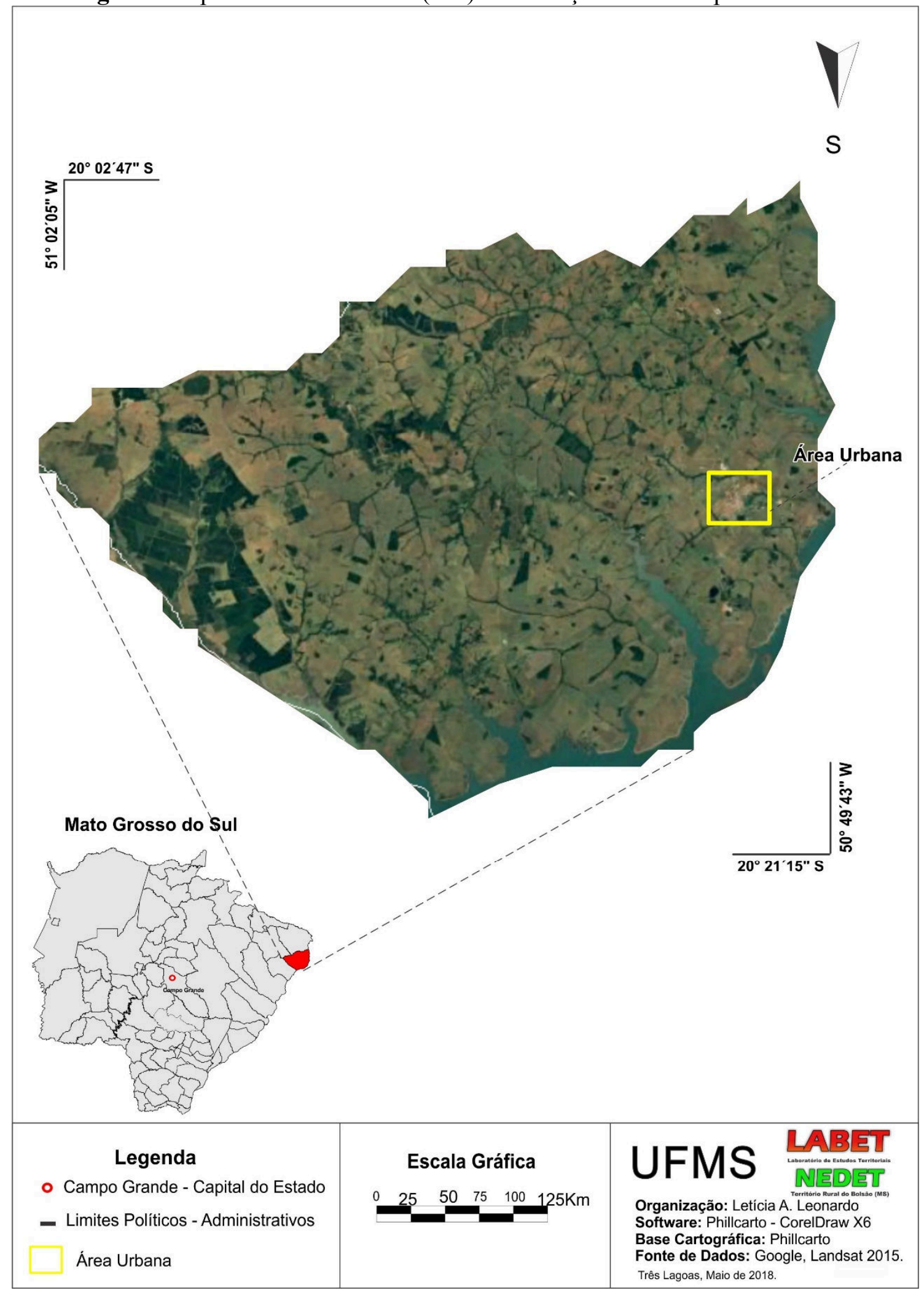

Fonte: Leonardo (2017). 
Figura 2: Território Rural do Bolsão (MS)

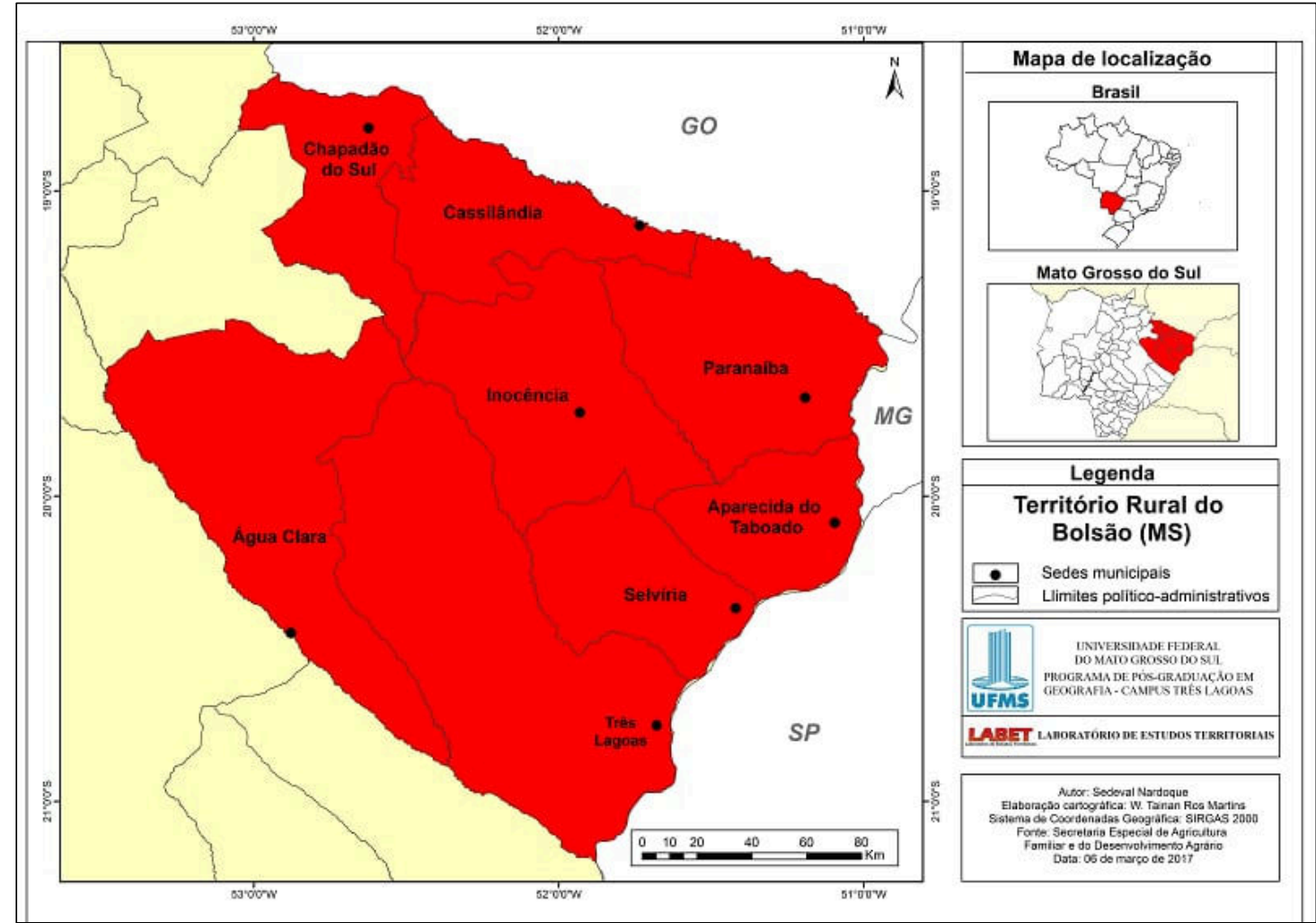

Fonte: Nardoque e Almeida (2015).

O município de Aparecida do Taboado tem como principais atividades econômicas a indústria, a pecuária e a agricultura, com destaque para a cana-de-açúcar. As monoculturas da cana-de-açúcar e do eucalipto expandiram-se pelo Território Rural do Bolsão nos últimos anos, resultante da territorialização do capital. Além da existência do agronegócio, sistema produtivo hegemônico na região, há também a presença de sistemas econômicos ligados à agricultura camponesa familiar, esta última, bem restrita e enfrenta enormes barreiras frente ao grande capital (NARDOQUE; ALMEIDA, 2015).

\section{Os agentes produtores do espaço urbano em Aparecida do Taboado (MS)}

A produção do espaço em Aparecida do Taboado, nos seus primeiros anos de formação, foi determinada por três agentes principais: o poder público, principalmente o municipal, por meio da produção de legislação específica que regulamentou o uso do solo no perímetro urbano, como por exemplo, o código de postura; por meio da implantação de infraestruturas, principalmente viárias, e, também, na construção de loteamentos 
populares e na disponibilização de créditos à habitação. Mas não foi o primeiro, pois houve a fundação e posterior emancipação.

Os proprietários rurais também foram importantes agentes atuando por meio da disponibilização de porções de terras para loteamento e, consequentemente, fundação e expansão da cidade.

A ação da Igreja Católica foi primordial na fundação, pois foi dela o primeiro loteamento da futura cidade. Além disso, a Igreja introduziu os mecanismos de extração de renda da terra urbana, baseadas na comercialização de lotes e na implantação do regime de enfiteuse, localizados na área central, originando Aparecida do Taboado.

\section{A fundação de Aparecida do Taboado (MS)}

Aparecida do Taboado tem sua gênese na antiga fazenda Córrego do Campo e sua fundação ocorreu por meio da vinda de "pioneiros", denominação dada por Cunha (2007). Esses sujeitos, sobretudo formadores de grandes posses, oriundos dos estados de São Paulo e Minas Gerais, vieram para a região por volta de 1900, fixando-se às margens do rio Paraná, no Porto Taboado, posteriormente denominado de Presidente Vargas.

Devido à intensidade do fluxo do porto às margens do rio Paraná, uma vez que era passagem obrigatória de gado para o Noroeste paulista, em direção a Barretos e São José do Rio Preto, surgiu, nas suas proximidades, o povoado de Lagoa Suja que, posteriormente, daria origem a Aparecida do Taboado. O povoado recebia esse nome devido à existência de uma lagoa nas proximidades coberta por vegetais denominados taboas (CUNHA, 2007, p. 29).

Na década de 1910, especificamente no ano de 1911, um dos proprietários rurais, Antônio Leandro de Menezes e sua mulher, Ana Maria do Nascimento, fizeram doação de uma gleba de terras de 48,4 hectares à Nossa Senhora Aparecida, em razão do cumprimento de uma promessa feita à santa, pois o filho do casal, Chico Leandro, tinha grave doença no ouvido e aos doze anos de idade foi curado. Para cumprir a promessa feita à santa, Antônio Leandro de Menezes doou os hectares de terras (CUNHA, 2007).

Contudo, a doação somente foi escriturada em nome da santa no ano de $1925^{7}$. Cunha (2007) assim a descreveu:

No dia 03 de agosto de 1925, Antônio Leandro de Menezes, sua esposa Ana Maria do Nascimento e o Reverendo Padre José Giardélli compareceram no 
cartório de Paranaíba para fazer a escritura de doação de 48.4 (quarenta e oito hectares e quatro ares de terra) a Nossa Senhora Aparecida, terra estas pertencentes à Fazenda Córrego do Campo, no lugar denominado Cabeceira Suja, onde encontra o cruzeiro com aguada no Rondina, vertente da Lagoa Suja. (CUNHA, 2007, p.31).

No dia 4 de agosto de 1925, Antônio Leandro de Menezes e sua esposa Ana Maria do Nascimento, voltaram ao cartório de Paranaíba e fizeram mais uma doação de 2,48 hectares à Nossa Senhora Aparecida ${ }^{8}$ (CUNHA, 2007).

No ano de 1940, João Alves Lara e sua esposa, Izaura Lopes Lara, também fizeram a doação de 9,68 hectares de terras à Nossa Senhora Aparecida ${ }^{9}$, no valor de Rs $200 \$ 000$ (duzentos mil réis). Juntas, as doações somaram 57.615,450 hectares de terras em nome da santa. Desta maneira, de posse das terras doadas à Nossa Senhora Aparecida, houve a fundação de Aparecida do Taboado pela Igreja Católica.

Em 1926, pela Lei Estadual $\mathrm{n}^{\mathrm{o}}$. 1012, de 01 de agosto daquele ano, foi criado o Distrito de Paz de Aparecida do Taboado, cuja área foi desmembrada do município de Paranaíba e, em 28 de setembro de 1948, foi elevado a município, pela Lei Estadual nº $130^{10}$.

\section{O regime de enfiteuse em Aparecida do Taboado (MS)}

$\mathrm{Na}$ sede do atual município, desde a sua fundação, instalou-se o regime de enfiteuse nos terrenos loteados pela Igreja Católica, localizados na parte central da cidade. A instalação desse regime de extração de renda da terra confere ao município uma característica peculiar, diferenciando-o dos demais municípios que integram o Território Rural do Bolsão.

O regime de enfiteuse foi instalado por meio das "terras de santo", ou seja, foram aforados os terrenos de propriedade da Igreja Católica, frutos de doações de proprietários rurais à santa padroeira da cidade, no caso, Nossa Senhora Aparecida. As doações foram realizadas em virtude de pagamento de promessas à santa padroeira e, também, para a formação do núcleo urbano, como escrito anteriormente.

No ano de 1943, a Prefeitura Municipal de Paranaíba publicou edital para legalizar a doação das terras, pois o prefeito em exercício à época entendia que a doação das terras à Nossa Senhora Aparecida não teria validade jurídica devido a santa não poder passar procuração, causando conflito com a Diocese de Corumbá, resolvendo-se a questão na 
justiça. A Mitra Diocesana de Corumbá ganhou o processo, em virtude de decisão favorável do juiz. As terras doadas foram loteadas pela Mitra Diocesana de Corumbá em 1948, conforme a figura 3, dando origem à cidade de Aparecida do Taboado (CUNHA, 2007).

Figura 3: Aparecida do Taboado (MS): quarteirões aforados com regime de enfiteuse

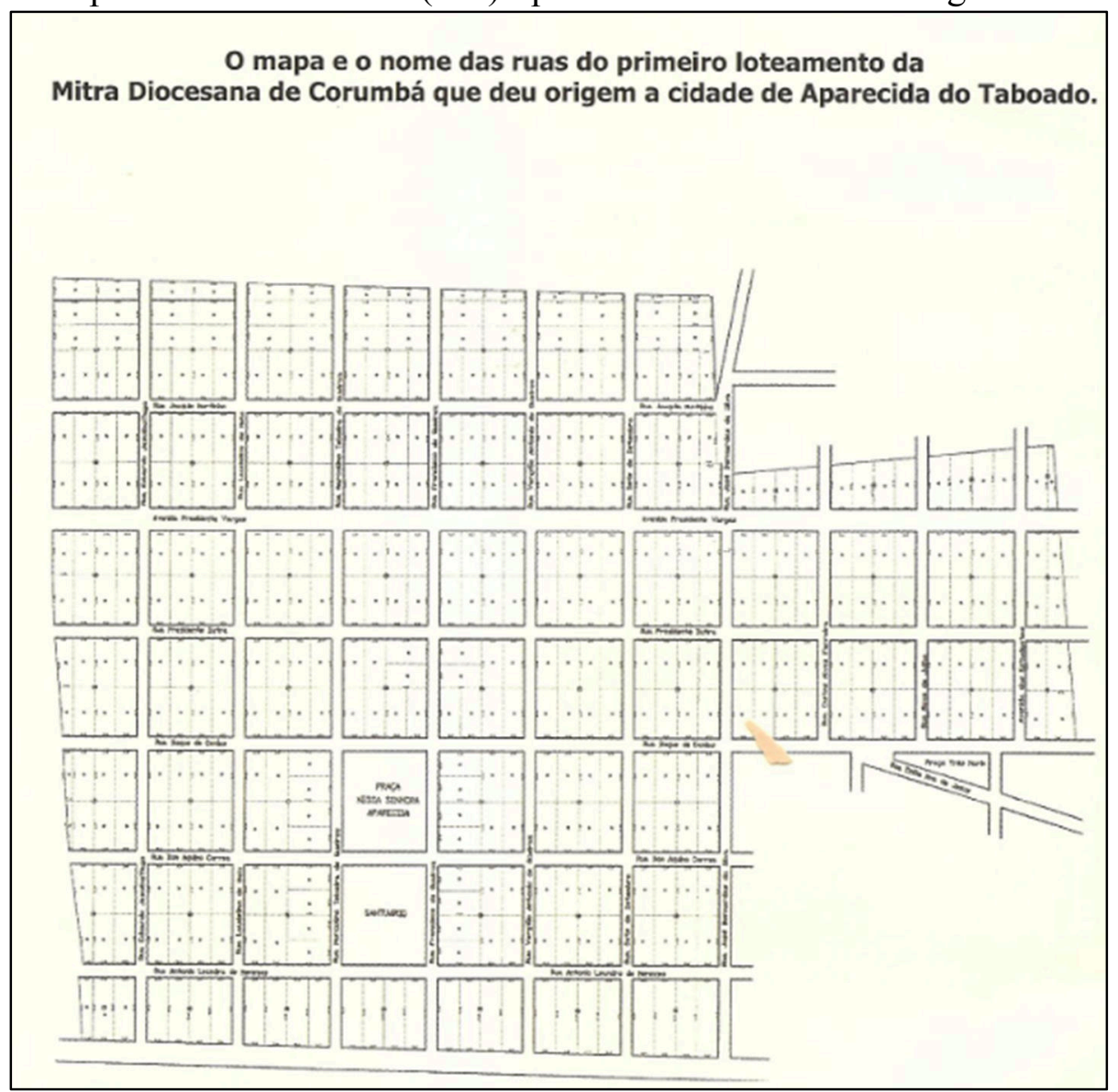

Fonte: Santuário Diocesano de Nossa Senhora Aparecida.

Os terrenos loteados pela Mitra Diocesana de Corumbá ${ }^{11}$ foram aforados com regime de enfiteuse ${ }^{12}$, caracterizando-se como um mecanismo de se extrair renda da terra por meio de cobrança de laudêmio. Nesse tipo de contrato, o senhorio (quem possui o domínio da terra) transfere a posse do terreno ou imóvel ao enfiteuta ou foreiro, contudo, o domínio ainda permanece com o senhorio, permitindo-lhe a cobrança de foro anual e laudêmio na comercialização futura do imóvel.

No caso de Aparecida do Taboado, o domínio direto ou pleno dos terrenos pertence ao Santuário Diocesano, ou seja, a figura do senhorio se encontra na Igreja Católica, enquanto o domínio útil é passado a particulares (enfiteutas), por meio de contratos de aforamento para concretização da comercialização dos terrenos aforados. 
A Igreja não transfere o direito de um terreno integralmente a terceiros, apenas cede o direito de utiliza-lo, ou seja, permite-os construírem casas ou estabelecimentos comerciais nos referidos terrenos. Enfim, de torná-los úteis. Os contratos de enfiteuse foram aforados em quadras localizadas aos arredores da Igreja Matriz, atualmente elevada a Santuário Diocesano.

A área total do patrimônio da santa era de $576.154,50 \mathrm{~m}^{2}$, distribuídos em 71 lotes irregulares, 68 lotes regulares (de 22x40) e 290 lotes regulares (de $22 \times 44)$ e duas praças ${ }^{13}$ (CUNHA, 2007, p. 29).

Os terrenos localizam-se na área central da cidade (setor 01), onde os mesmos possuem preços mais elevados em relação aos demais localizados em outros bairros da cidade, devido a sua localização privilegiada, ou seja, na principal área residencial e comercial.

$\mathrm{O}$ quadro 1 demonstra a diferença de valores do $\mathrm{m}^{2}$ entre os terrenos da cidade. No estabelecimento do valor venal, os bairros são divididos por setores, totalizando 17 .

Quadro 1: Aparecida do Taboado (MS): valores venais dos terrenos - 2016

\begin{tabular}{|c|c|}
\hline SETOR & PREÇO por $\mathbf{~ m}^{\mathbf{2}}$ em RS \\
\hline 1 & 68,75 \\
\hline 2 & 62,14 \\
\hline 3 & 54,76 \\
\hline 4 & 48,18 \\
\hline 5 & 40,98 \\
\hline 6 & 37,75 \\
\hline 7 & 34,37 \\
\hline 8 & 31,03 \\
\hline 9 & 27,12 \\
\hline 10 & 23,73 \\
\hline 11 & 20,40 \\
\hline 12 & 17,12 \\
\hline 13 & 13,23 \\
\hline 14 & 9,95 \\
\hline 15 & 7,69 \\
\hline 16 & 5,49 \\
\hline 17 & 3,80 \\
\hline
\end{tabular}

Fonte: Prefeitura Municipal de Aparecida do Taboado (MS).

O valor venal dos terrenos é usado como base para a cobrança do Imposto Predial e Territorial Urbano (IPTU) e para a cobrança do Imposto sobre Transmissão de Bens Imóveis Inter-Vivos (ITBI). O quadro permite fazer a comparação do preço entre os 
terrenos, sendo que a área central da cidade compreende o setor 1, onde os terrenos têm preços maiores por metro quadrado, no caso, $\mathrm{R} \$ 68,75$ (sessenta e oito reais e setenta e cinco centavos).

Ao comparar com os preços de outros bairros, como por exemplo, os mais afastados, como os do setor 14 ou bairros recém-lançados (setor 17), percebe-se a diferença significativa entre eles, atingindo a variação de, aproximadamente, $R \$ 65,00$ (sessenta e cinco reais) por $\mathrm{m}^{2}$. Essa significativa variação de preço, e, consequentemente, dos lotes/terrenos, é devido à localização em relação a áreas de maior interesse, como centro comercial, áreas de lazer, avenidas, por exemplo. A área central compreende significativa parte da cidade, como se observa na figura 4.

Nos referidos terrenos, desmembrados das glebas originárias de terras, doadas por Antônio Leandro de Menezes e João Alves Lara e aforados com regime enfitêutico pela Igreja Católica, encontram-se casas residenciais e, devido à área ser o centro comercial da cidade, localizam-se, também, inúmeros prédios comerciais, lojas de alimentação e clínicas médicas particulares, além de escola municipal.

Quando algum proprietário de terreno não edificado ou imóvel residencial ou comercial, localizado nesta área central decide vender o imóvel aforado sob o regime e o Santuário Diocesano abdica do seu direito de recompra, o referido proprietário do terreno tem de pagar o laudêmio à Igreja, conferindo apropriação da renda da terra à Igreja.

O laudêmio corresponde a $2,5 \%$ do valor venal do imóvel, ou seja, tal como ele se encontrava no momento da realização do contrato, não podendo a Igreja Católica cobrar por benfeitorias realizadas no terreno. No caso de Aparecida do Taboado, a modalidade de taxação correspondente ao foro anual ou pensão não foi instituída nos contratos e, por isso, não é cobrada, somente o laudêmio. 
Figura 4: Aparecida do Taboado (MS): localização dos quarteirões aforados com regime de enfiteuse

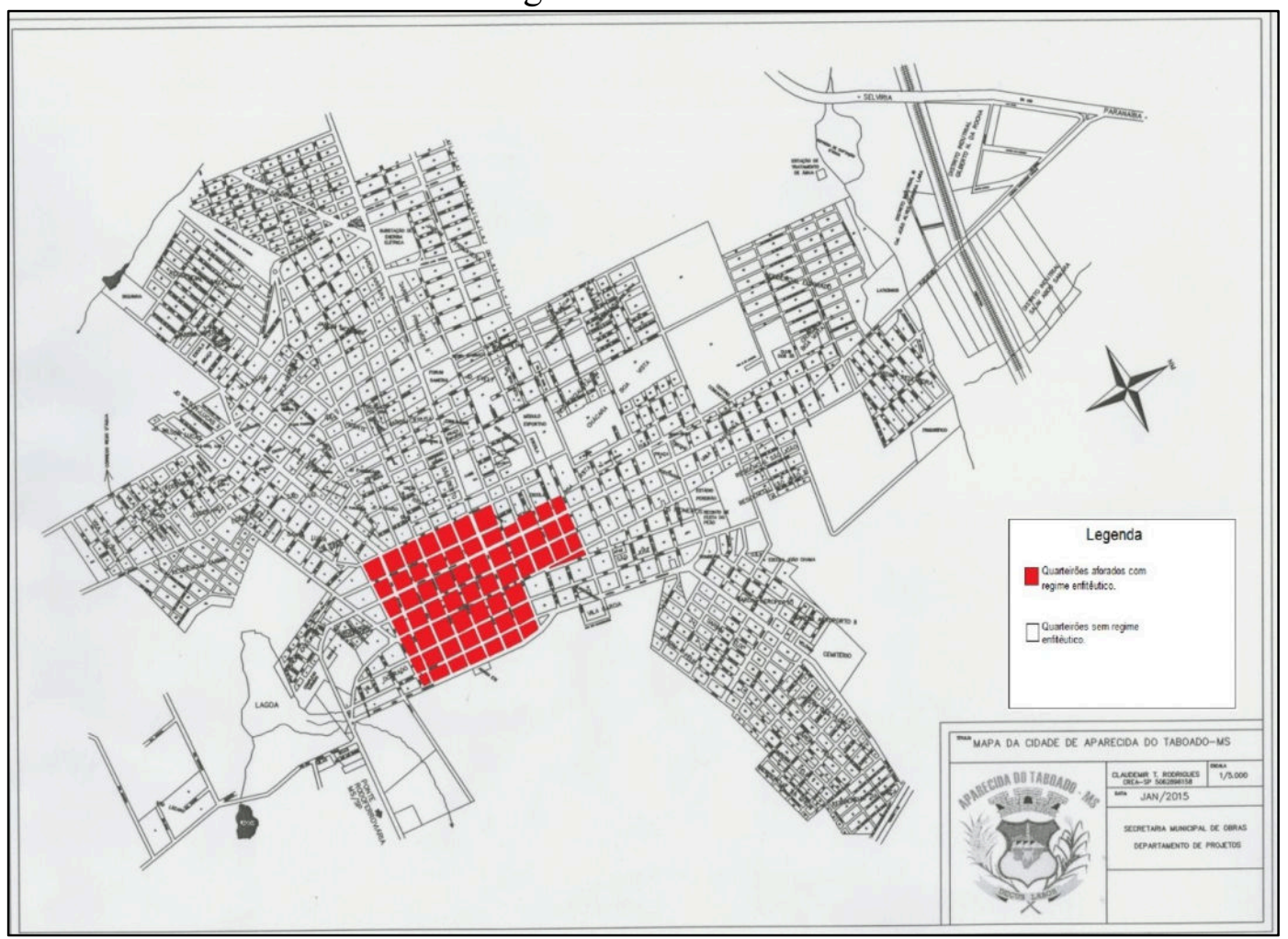

Fonte: Prefeitura Municipal de Aparecida do Taboado (MS).

A maioria da população aparecidense desconhece tal modalidade de extração de renda da terra por meio da cobrança de laudêmio. O regime de enfiteuse não é de conhecimento de todos e somente aqueles que têm imóveis residenciais ou comerciais conhecem tal modalidade de contrato e de propriedade fundiária com aforamento. Por isso, nesta parte da cidade a Igreja foi e é importante agente na produção do espaço em Aparecida do Taboado, seja por meio do loteamento inicial e na comercialização de terrenos via contratos de enfiteuse ou por meio da cobrança de laudêmio nas transações imobiliárias na área com o metro quadrado mais caro da cidade, auferindo-se renda da terra.

\section{REFLEXÕES À GUISA DE CONCLUSÃO}

Durante o processo de formação do atual município de Aparecida do Taboado, a Igreja Católica exerceu grande influência, pois possuía e possui terras sob seu domínio na região central da cidade e, com isso, apropria-se de renda da terra por meio de contratos de enfiteuse e da cobrança do laudêmio.

A extração de renda da terra, via regime de enfiteuse, em Aparecida do Taboado, é realizada na área central da cidade, onde a Igreja Católica aforou sob o regime enfitêutico, 
dessa forma, alienando parte do espaço, rendendo ganhos extraordinários por meio da cobrança do laudêmio, resultando em renda da terra, visto que os terrenos aforados são os que possuem maiores preços devido à localização privilegiada, no centro da cidade.

O que mais impressiona é o fato de que, mesmo sob um Estado neoliberal, ainda existem resquícios do colonialismo, do patrimonialismo e do sistema feudal, como o regime de enfiteuse. Regime este que representa barreiras ao capitalismo para a apropriação e (re)produção do espaço, pois o regime enfitêutico se mostra como um problema ao capitalismo devido ao fato de estabelecer uma barreira ao sistema, impossibilitando a apropriação total do território pelo capital, pois separa posse e domínio, alicerces da propriedade capitalista da terra. Além disso, implica em extração da renda da terra pela Igreja Católica, contribuindo para apropriação da mais-valia do conjunto da sociedade, no momento da comercialização de imóveis residenciais ou comerciais na área central de Aparecida do Taboado.

Percebe-se que, ainda hoje, os espaços são regidos por normas que foram instituídas no passado, no processo histórico. É necessário entendê-las e como influenciaram na produção do espaço, sobretudo para se compreender os espaços atuais e sua reprodução.

Sendo que, se não se compreender, os agentes, as normas e as formas como o espaço foi apropriado na acumulação dos tempos pretéritos, não o entenderá em tempo presente, nem mesmo ter-se-á capacidade de intervir de forma eficaz sobre ele. Sendo assim, para compreender o espaço geográfico e sua produção e reprodução, não basta analisar-se somente suas formas atuais, mas é necessário compreendê-las no seu processo histórico de formação.

As normas jurídicas instituídas no passado, que regiam a forma de apropriação do espaço, ainda se fazem valer nos dias atuais. O regime de enfiteuse e a cobrança do laudêmio são exemplos claros disso, sobretudo pela validade na norma jurídica instituída pelo Estado e efetivada pelo agente produtor do espaço em Aparecida do Taboado, no caso a Igreja, apropriando-se da renda terra.

É por meio da compreensão desses processos, ocorridos no passado, ser imprescindível o entendimento das normas e os espaços atuais e, dessa forma, pensa-lo em sua (re)produção de maneira mais crítica. 


\section{Notas}

1 A autora principal foi bolsista, via CNPq, de iniciação à extensão no referido projeto e o segundo autor, o coordenador do projeto.

2 Código Civil de 1996, disponível em: <http://www2.camara.leg.br/legin/fed/lei/1910-1919/lei-3071-1janeiro-1916-397989-publicacaooriginal-1-pl.html $>$. Acesso em: 9 jun. 2015.

3 Disponível em: < http://www.planalto.gov.br/ccivil_03/constituicao/constituicaocompilado.htm>. Acesso em 05 jan.2017.

4 Disponível em: <http://www.planalto.gov.br/ccivil_03/decreto-lei/Del9760.htm>. Acesso em 05 jan. 2017.

5 A Microrregião é composta pelos municípios de: Aparecida do Taboado, Inocência, Paranaíba e Selvíria. Instituto Brasileiro de Geografia e Estatística (IBGE). Disponível em: $<$ http://www.cidades.ibge.gov.br/xtras/perfil.php?codmun=500100\&search=mato-grosso-dosul\%7Caparecida-do-taboado\&lang $=>$. Acesso em: 8 mai. 2015.

${ }^{6}$ O memorialista Cunha (2007) denomina de pioneiros, os cidadãos que vieram para Aparecida do Taboado e aqui fixaram residência antes da formação do município, entendendo o termo pioneiro como aquele que veio primeiro, o indivíduo que descobriu o caminho para regiões desconhecidas. Neste trabalho, refuta-se o uso deste termo, pois entende-se que, antes da vinda desses sujeitos, proprietários fundiários, havia ocupação prévia do local, a população nativa, que residia há muito no local, não sendo uma região desconhecida, além de pequenos posseiros.

7 A doação ficou registrada na folha $n^{\circ} 93$ do livro de notas $n^{\circ} 31$, do Tabelião de Notas da Comarca de Paranaíba/MS, conforme indicação do livro Aparecida do Taboado - O Portal do Desenvolvimento, do escritor Marley Cunha.

8 Doação registrada na folha 68, do livro "Transcrição de Imóveis", sob número 3-B, número de ordem 1696.

${ }^{9}$ Escritura pública lavrada no livro 02 de notas, folhas 09 a 11, no cartório de Aparecida do Taboado/MS.

10 Importante ressaltar que, na época em que foi criado o município de Aparecida do Taboado, o mesmo pertencia ao estado de Mato Grosso, sendo que, no dia 11 de outubro de 1977, o presidente Geisel criou o estado do Mato grosso do Sul pela lei complementar $n^{\circ}$. 31, com capital em Campo Grande, tendo sua instalação ocorrida no dia $1^{\circ}$ de janeiro de 1979.

${ }^{11}$ No ano de 1908, criou-se a Diocese de Três Lagoas e Aparecida do Taboado passou a integrar esta nova jurisdição eclesiástica.

12 Certidão de registro de loteamento inscrita sob o número 2, folhas $1 / 3 \mathrm{~V}$. do L Anexo 8.

13 Os Lotes irregulares compreendem a área de $70.171,50 \mathrm{~m}^{2}$. Os lotes regulares, de tamanho $22 \times 40$, ocupam $59.840,00 \mathrm{~m}^{2}$, os regulares, de tamanho $22 \mathrm{x} 44$, ocupam $280.720,00 \mathrm{~m}^{2}$. Enquanto as duas praças têm área $1.936,00 \mathrm{~m}^{2}$. (CUNHA, 2007, p. 29).

\section{REFERÊNCIAS}

ABREU, M. A. A apropriação do território no Brasil colonial. In: CASTRO, Iná Elias; CORREAA, Roberto Lobato; GOMES, Paulo C. da. (org.). Explorações geográficas. Rio de Janeiro: Bertrand Brasil, 1997.

BARRETO, C. G. P. Renda Fundiária, Legislação Urbanística, Disputa de Usos do Solo: a transformação da Avenida 17 de agosto em eixo comercial ao longo da última década. 2012. Dissertação (Mestrado em Desenvolvimento Urbano) - Universidade Federal de Pernambuco, Recife, 2012.

BOTELHO, Adriano. A cidade como negócio: produção do espaço e acumulação do capital no município de São Paulo. São Paulo: Cadernos Metrópole, n. 18. p. 15-38. 2007.

CARLOS, A. F. A. A cidade. São Paulo: Contexto, 1992. 
A condição espacial. São Paulo: Contexto, 2011.

CORRÊA, R. L. Trajetórias geográficas. Rio de Janeiro: Bertrand Brasil, 1997.

O espaço urbano. São Paulo: Ática, 2005.

Sobre agentes sociais, escala e produção do espaço: um texto para discussão. In: CARLOS, Ana Fani Alessandri; SOUZA, Marcelo Lopes de; SPOSITO, Maria Encarnação Beltrão. (org.) A produção do espaço urbano: agentes e processos, escalas e desafios. São Paulo: Contexto, 2012. Cap. 11, p. 234.

CUNHA, Marley. Aparecida do Taboado - o portal do desenvolvimento. Aparecida do Taboado, acervo municipal, 2007.

GADELHA, R. M. D. F. A lei de terra (1850) e a abolição da escravidão, capitalismo e força de trabalho no Brasil do século XIX. Revista de História, São Paulo, n.120, p. 153$162,1989$.

GHIRARDELLO, N. À beira da linha: formações urbanas da Noroeste Paulista. São Paulo: Editora UNESP, 2002.

JUCÁ NETO, C. R. Os primórdios da organização do espaço territorial e da vila cearense: algumas notas. Anais do Museu Paulista. São Paulo. v.20. n.1, 2012. Disponível em: $<$ http://www.scielo.br/scielo.php?pid $=$ S010147142012000100006\&script $=$ sci_artte xt>. Acesso em: 15 dez. 2016.

LEONARDO, L.A. O regime de enfiteuse e a extração de renda da terra em Aparecida do Taboado (MS). 58 f. Monografia - Universidade Federal do Mato Grosso do Sul, Três lagoas, 2017.

NARDOQUE, Sedeval. Apropriação capitalista da terra e a formação da pequena propriedade em Jales-SP. 214 f. Dissertação (Mestrado em Geografia) - Universidade Estadual Paulista, Faculdade de Ciências e Tecnologia, Presidente Prudente, 2002.

Apropriação capitalista da terra e a desconcentração fundiária Jales - SP. 1. ed. Dourados: EDUFGD, 2014.

Renda da terra e produção do espaço urbano em Jales - SP. 445 f. Tese (Doutorado em Geografia) - Instituto de Geociências e Ciências Exatas/Universidade Estadual Paulista, Rio Claro, 2007.

NARDOQUE, Sedeval; GERARDI, Lúcia Helena de Oliveira. Renda da terra e a produção do espaço urbano em Jales. Scripta Nova (Barcelona), Espanha, v. IX, n.194, p. $12,2005$.

A renda da terra e a produção do espaço urbano em Jales. In: ORTIGOZA, S.A.G.; GERARDI, L.H.O.. (Org.). Temas da Geografia Contemporânea. Rio Claro: AGETEO/Programa de Pós-graduação em Geografia, 2009. 
NARDOQUE, S; ALMEIDA, R. A. Da. Território Rural do Bolsão (MS): realidade e perspectivas. Revista Nera, v. 1, n. 85, p.2-8, 2015.

OLIVEIRA, A. U. Modo de produção capitalista, agricultura e reforma agrária. São Paulo: Labur Edições, 2007, 184 p.

Agricultura e Indústria no Brasil. CAMPO-TERRITÓRIO: Revista de geografia agrária, São Paulo, n.10, v.5, p. 5-64, ago. 2010.

OLIVEIRA FILHO, J. C. A. De; COSTA, O. J. L. Produção contraditória do espaço urbano: a Igreja e os movimentos sociais na Cidade do Crato - Ceará. Revista do Departamento de Geografia, v. 32. p.108-123, 2016.

ROSENDAHL, Z. O sagrado e o espaço. In: CASTRO, Iná Elias; CORREAA, Roberto Lobato; GOMES, Paulo C. Da. (org.). Explorações geográficas. Rio de Janeiro: Bertrand Brasil, 1997.

SANTOS, Alexandre. E. Do surgimento da cidade ao processo de conurbação: elementos teóricos para análise. VII Encontro Brasileiro dos Geógrafos. Vitória - ES. 2014.

SILVA, Cleiton. F. Da. O capitalismo monopolista e a renda da terra urbana na cidade mercadoria: uma discussão sobre o empreendimento "novo recife". Revista Pegada, vol. 16, n.1, p. 225-249, 2015.

SILVA, Lenyra. R. Da. A natureza contraditória do espaço geográfico. São Paulo: Contexto, 1991. $100 \mathrm{p}$.

SPÓSITO, Eliseu S. A vida nas cidades. 2. ed. São Paulo: Contexto, 1996.

SPOSITO, Maria E. B. O chão arranha o céu: a lógica da (re)produção monopolista da cidade, 1991. 383 f. Tese (Doutorado em Geografia Humana) - Faculdade de Filosofia, Letras e Ciências Humanas, Universidade de São Paulo, São Paulo, 1991.

VASCONCELOS, P. M. Os agentes modeladores das cidades brasileiras no período colonial. In: CASTRO, Iná Elias; CORRÊA, Roberto Lobato; GOMES, Paulo C. da. (org.). Explorações geográficas. Rio de Janeiro: Bertrand Brasil, 1997.

ZANOTELLI, C. L; FERREIRA, F. C. O espaço urbano e a renda da terra. Geo Textos, vol. 10, n. 1, p. 35-58, jul. 2014.

Recebido em 30/04/2017

Aceito para publicação em 19/04/2018. 